\title{
FORMULASI FOOD BAR GRITS KACANG KOMAK DAN KACANG KEDELAI HITAM MENGGUNAKAN METODE LINEAR PROGRAMMING
}

\section{FORMULATION OF LABLAB BEAN AND BLACK SOYBEAN FOOD BAR GRITS USING LINEAR PROGRAMMING METHOD}

\author{
Hosnariyah Khair Fath, Ishmah Hanifah, Widya Dwi Rukmi Putri \\ Jurusan Teknologi Hasil Pertanian, FTP Universitas Brawijaya \\ Jl. Veteran, Malang 65145 \\ email: ishmahhanifah8@gmail.com
}

Diserahkan [16 Mei 2020]; Diterima [13 Juli 2020]; Dipublikasi [22 Juli 2020]

\begin{abstract}
Lablab bean and black soybean have high productivity and nutritional content. Both of these commodities have not been optimized as a food diversification yet, therefore their commodity value is considerably low. Commodity value can be improved by processing the commodity into food product such as food bar. Food bar is a ready to eat snack and contain high calorie and nutrition. The purpose of this research is to figured out the food bar formula that expected to give an effect of satiation, measuring the consumer's acceptance and determining the physicochemical and organoleptic aspect of food bar. The formulation was conducted by linear programming. All food bars were analyzed chemically, organoleptically and level of satiation. The result is analyzed by Friedman Test, then. The best treatment was determined by effectivity index and multiple attribute method. The best treatment of food bar was analyzed physically and compared to a commercial product with three replication. The result was analyzed by General Linear Model and Fisher Test on Minitab 17. Food bar which has the highest protein is the best formula. Its chemical characteristics contain $7.18 \%$ moisture, $2.67 \%$ ash, $13.07 \%$ protein, $19.00 \% \mathrm{fat}, 58.08 \%$ carbohydrate, $3.14 \%$ crude fiber, and $227.80 \mathrm{kcal} / 50 \mathrm{~g}$ calorie. Organoleptic values are 3.575 for color (like), 3.750 for aroma (like), 3.700 for flavour (like), 3.425 for texture (neutral); 6.65 for satiation, 7.29 for hunger, 5.18 for desires to eat, 6.87 for satisfaction, and 3.95 for satiation index. Physical characteristics have the level of brightness 44.3; degree of redness 4.3; degree of yellowness 12.3; and texture $-32.6 \mathrm{~N} / \mathrm{m}^{2}$.
\end{abstract}

Keywords : black soybean, food bar, lablab bean, linear programming

\section{ABSTRAK}

Kacang komak dan kacang kedelai hitam memiliki produktivitas dan kandungan gizi yang tinggi. Kedua komoditas tersebut belum banyak dimanfaatkan sebagai diversifikasi produk pangan, sehingga membuat nilai tambah komoditas menjadi rendah. Nilai tambah komoditas dapat ditingkatkan dengan cara diolah menjadi produk pangan seperti food bar. Food bar merupakan makanan siap santap, praktis, memiliki kalori dan nutrisi yang tinggi. Penelitian ini bertujuan untuk mengetahui formula food bar yang diharapkan mampu memberikan efek kenyang, mengetahui tingkat penerimaan konsumen, sifat fisikokimia, dan organoleptik food bar yang dihasilkan. Formulasi food bar dilakukan menggunakan metode linear programming. Food bar hasil formulasi dilakukan uji kimia, uji organoleptik dan tingkat kenyang. Data yang diperoleh dianalisa menggunakan Friedman Test. Perlakuan terbaik ditentukan berdasarkan metode indeks efektivitas dan multiple attribute. Food bar perlakuan terbaik selanjutnya dilakukan uji fisik dan dibandingkan dengan produk komersial dengan 3 ulangan. Hasil penelitian dianalisa menggunakan General Linear Model dengan uji lanjut menggunakan Fisher Test pada Minitab 17. Formula Food bar dengan kandungan protein yang paling tinggi merupakan formula terbaik dengan karakteristik kimia yang didapatkan, yaitu 7.18\% air, 2.67\% abu, $13.07 \%$ protein, $19.00 \%$ lemak, $58.08 \%$ karbohidrat, $3.14 \%$ serat kasar, dan $227.80 \mathrm{kkal} / 50 \mathrm{~g}$ total kalori. Karakteristik organoleptik dengan ratarata warna 3.575 (suka); aroma 3.750 (suka); rasa 3.700 (suka); tekstur 3.425 (biasa) dan tingkat kenyang seperti 6.65 kenyang, 7.29 lapar, 5.18 keinginan makan, 6.87 kepuasan, dan 3.95 indeks kenyang. Karakteristik fisik seperti tingkat kecerahan 44.3; tingkat kemerahan 4.3; tingkat kekuningan 12.3; dan daya patah $-32.6 \mathrm{~N} / \mathrm{m}^{2}$.

Kata kunci : food bar; kacang kedelai; kacang komak; linear programming

\section{PENDAHULUAN}

Kacang komak merupakan jenis kacangkacangan asli Indonesia yang banyak ditanam di daerah Jawa Timur dan Nusa Tenggara Barat. Produktivitas kacang komak tergolong tinggi yaitu mencapai 1.0-1.2 ton/ha (Sudjarwo et al., 2014). Kandungan serat pangan pada kacang komak mampu membantu mengontrol kadar lemak penyebab hiperkolesterolemia dan penyakitpenyakit kardiovaskular (Febrial, 2009). 
Berdasarkan analisa Mosisa dan Tura (2017), kandungan gizi pada kacang komak mentah cukup tinggi yaitu $24.63 \%$ protein, $0.90 \%$ lemak, $65.85 \%$ karbohidrat, dan $4.63 \%$ serat.

Komoditas yang juga dinilai penting untuk dimanfaatkan adalah kacang kedelai hitam, terutama jika dibandingkan dengan kacang kedelai kuning (Fetriyuna, 2015). Kandungan serat dalam kacang kedelai hitam bermanfaat untuk membantu sistem pencernaan, menurunkan tingkat kolesterol jahat dalam darah, dan menjaga tekanan darah stabil (Balitbangtan, 2008). Pada tahun 2008, Badan Litbang Pertanian melepas varietas kacang kedelai hitam baru yaitu Detam 1 dan Detam 2. Detam 1 memiliki potensi hasil hingga 3.45 ton/ha (Badan Litbang Pertanian, 2012). Berdasarkan analisis Putri et al. (2016), Detam 1 memiliki kandungan gizi sebesar $36.50 \%$ protein, $14.59 \%$ lemak, dan $43.11 \%$ karbohidrat sedangkan serat sebesar $7.51 \%$ (Patel dan Pandya, 2014). Kedua komoditas kacangkacangan tersebut dinilai penting sebagai sumber protein nabati. Namun, belum banyak dimanfaatkan sebagai diversifikasi produk pangan.

Pangan darurat (Emergency Food Product) adalah pangan yang diproduksi untuk kondisi darurat yang harus dapat dikonsumsi secara langsung (ready to eat) untuk memenuhi kebutuhan nutrisi harian (Syamsir dan Sitanggang, 2011). Beberapa contoh kondisi darurat adalah saat waktu makan yang tersedia sedikit bagi orang-orang sibuk, saat tidak tersedianya makanan berat sehingga dibutuhkan makanan penunda lapar, saat bencana, serta saat perang terjadi (Rahman et al., 2011). Emergency Food Product didesain dapat memiliki kandungan energi yang sesuai dengan rekomendasi Zoumas et al. (2002) yaitu memiliki kandungan lemak sebesar 19-24 g/100 g, protein 12-18 g/100 g, dan karbohidrat 48$60 / 100$ g. Adapun persentase kalori pada setiap zat gizi yaitu 35-45 \% untuk lemak, $10-15 \%$ untuk protein dan $40-50 \%$ untuk karbohidrat.

Salah satu contoh produk pangan darurat adalah food bar. Food bar adalah produk pangan padat ready to eat yang berbentuk batang dan merupakan campuran dari berbagai bahan kering seperti sereal, kacang-kacangan, buah-buahan kering yang digabungkan menjadi satu dengan bantuan binder (Rahman et al., 2011). Binder dapat berperan dalam memperbaiki sifat fisik makanan padat yang agar lebih kompak dan tidak mudah hancur saat pendistribusian (Ladamay dan Yuwono, 2014). Binder merupakan gabungan dari bahan pemanis dan berlemak yang digunakan untuk menyatukan bahan-bahan kering menjadi bentuk batang (bar) (Ying et al., 2018). Food bar umumnya mengandung gula yang dapat berperan sebagai binder atau pemberi rasa manis (Pallavi et al., 2013). Binder dalam foodbar dapat berupa sirup dan karamel (Aminah et al., 2019).

Penyusunan formula food bar pada penelitian ini menggunakan metode linear programming. Linear programming merupakan bagian dari riset operasional, yaitu proses pencarian cara untuk menentukan tindakan yang terbaik atau optimal dari suatu pengambilan keputusan dalam situasi sumber-sumber daya yang terbatas (Ibnas, 2014). Konsumsi produk bertujuan untuk mendapatkan rasa kenyang tertentu. Rasa kenyang (satiation) mengarah pada proses yang terjadi selama makan berlangsung dan saat akan berhenti makan (Karalus, 2011). Daya kenyang makanan bergantung pada jumlah protein, karbohidrat, lemak dan serat yang dikandungnya (Chambers et al., 2015). Serat makanan dan protein dinilai mampu mewakili dua makronutrien paling ampuh untuk mendorong respon kenyang (Jakobsen, 2015).

Berdasarkan uraian tersebut, kacangkacangan seperti kacang komak dan kacang kedelai hitam juga memiliki potensi untuk dimanfaatkan sebagai bahan baku formulasi food bar siap santap. Oleh karena itu, penelitian ini bertujuan untuk memperoleh formulasi food bar berbasis kacang komak dan kacang kedelai hitam sebagai alternatif makanan siap santap bernutrisi yang diharapkan mampu memberikan efek kenyang dan menunda lapar serta mengetahui penerimaan konsumen, karakteristik organoleptik dan fisikokimia food bar yang dihasilkan. 


\section{METODE PENELITIAN}

\section{Bahan}

Bahan yang digunakan dalam penelitian ini adalah kacang kedelai hitam varietas Detam 1 yang diperoleh dari Balai Penelitian Tanaman Aneka Kacang dan Umbi (Balitkabi) Kota Malang, kacang komak hijau segar yang diperoleh dari pasar tradisional Probolinggo, natrium bikarbonat (Pudak Scientifik, Indonesia) yang diperoleh dari CV. Makmur Sejati, margarin (Simas Palmia, Salim Ivomas Pratama, Indonesia), madu (Tresno Joyo, Ultra Sakti, Indonesia), pasta vanili (Red Bell, Verra Cosmetics, Indonesia), cokelat susu blok (Colatta, Gandum Mas Kencana, Indonesia) gula merah curah, kertas kue, dan sarung tangan plastik yang diperoleh dari Toko Bahan Kue Prima.

Bahan yang digunakan untuk analisis antara lain tablet Kjeldahl (Kjeltabs CX, Thompson and Chapper, Inggris), larutan $\mathrm{NaOH} 30 \%$ (Merck Chemical and Life Sciences, Jerman), larutan $\mathrm{HCl} 0.1 \mathrm{~N}$ (Merck Chemical and Life Sciences, Jerman), larutan indikator pp (Smart-Lab Indonesia, Indonesia), larutan indikator MM (Nirwana Abadi, Indonesia), aquades, Petroleum Eter (Full Time, Murni Dharma Karya, Indonesia), larutan $\mathrm{H}_{2} \mathrm{SO}_{4} 0.225 \mathrm{~N}$ (Merck Chemical and Life Sciences, Jerman), kertas lakmus merah dan biru, larutan $\mathrm{NaOH} 0.313$ $\mathrm{N}$ (Merck Chemical and Life Sciences, Jerman), larutan $\mathrm{K}_{2} \mathrm{SO}_{4} \quad 10 \%$ (Pudak Scientifik, Indonesia), dan etanol $96 \%$ (Merck Chemical and Life Sciences, Jerman) yang diperoleh ecer dari Toko Kimia Krida Tama. Larutan $\mathrm{H}_{2} \mathrm{SO}_{4}$ pekat (Merck Chemical and Life Sciences, Jerman) dan larutan $\mathrm{H}_{3} \mathrm{BO}_{3} \quad 3 \%$ (Smart-Lab Indonesia, Indonesia) yang diperoleh dari Laboratorium Kimia dan Biokimia Pangan Universitas Brawijaya.

\section{Alat}

Alat yang digunakan dalam penelitian ini adalah alat pengolahan food bar yang terdiri dari timbangan digital (W7SD-CL5S Digiscala Clarita, Weston, Tiongkok), kompor gas (Rinnai RI-522E, Jepang), termometer, cabinet dryer, disc mill, ayakan
10 mesh, wajan, loyang, oven listrik (CO9919R Cosmos, Indonesia), refrigerator (GN-B572LCL LG, Korea Selatan), sedangkan alat analisis food bar diantaranya alat gelas, oven udara (UM 500 Memmert, India), cawan alumunium, cawan porselen, desikator, timbangan analitik (TP-1502 Denver Instrument, AS), tanur pengabuan (Benchtop 1100 C Muffle Furnace Thermolyne, Amerika), pemanas, alat soxhlet lengkap dengan kondensor (Classic Soxhlet Apparatus Gerhardt, Jerman), kertas saring kasar, digester Kjeldahl yang dihubungkan dengan pengisap uap melalui aspirator (K436 Buchi, Swiss), labu Kjeldahl, alat distilasi lengkap (K-350 Buchi, Swiss), corong buchner dan pompa vakum, color reader (CR-10 Konica Minolta, Jepang), dan Texture Analyzer (TA.XT Plus, Inggris).

\section{Penelitian pendahuluan}

Penelitian pendahuluan dilakukan untuk menentukan perlakuan awal pada kacang komak dan kacang kedelai hitam sebelum dibuat grits. Perlakuan awal yang dilakukan yaitu pencucian, perendaman dengan natrium bikarbonat, pemblansiran, pegeringan, penggilingan dan pengayakan. Kacang yang telah diberi perlakuan awal selanjutnya ditentukan metode pembuatan grits. Selain itu, menentukan bahan dan prosedur pembuatan food bar serta menentukan batas jumlah bahan yang digunakan (minimal dan maksimal). Basis formula food bar yang digunakan terdapat pada Tabel 1.

Tabel 1 Basis formula food bar

\begin{tabular}{lcc}
\hline \multicolumn{1}{c}{ Bahan } & $\begin{array}{c}\text { Jumlah } \\
(\mathrm{g})\end{array}$ & $\begin{array}{c}\text { Persentase } \\
(\%)\end{array}$ \\
\hline grits Detam 1 & 25 & 20 \\
grits kacang & 25 & 20 \\
komak & & \\
margarin & 14 & 11 \\
madu & 14 & 11 \\
gula merah & 14 & 11 \\
cokelat susu & 31 & 25 \\
vanili & 2.5 & 2 \\
jumlah & 125.5 & 100 \\
\hline
\end{tabular}




\section{Tahapan Penelitian}

\section{Pembuatan Grits Kacang Kedelai Hitam}

Prinsip pembuatan grits pada kacang kedelai hitam dan kacang komak adalah sama. Pembuatan grits diawali dengan penyortiran dan pencucian kacang untuk menghilangkan kotoran yang menempel pada permukaan. Selanjutnya, perendaman dilakukan selama 3 jam utnuk kacang kedelai hitam dan 6 jam untuk kacang komak dengan perbandingan kacang dan air adalah $1: 5 \mathrm{w} / \mathrm{v}$ serta diberikan natrium bikarbonat sebanyak $0.5 \%$ dari berat total. Setelah itu, dilakukan pemblansiran selama 15 menit pada suhu 75 ${ }^{\circ} \mathrm{C}$ untuk kacang kedelai hitam dan 20 menit pada suhu $70{ }^{\circ} \mathrm{C}$ untuk kacang komak. Kacang tersebut kemudian ditiriskan. Perlakuan untuk kacang komak dilakukan pengupasan kulit. Pengeringan dilakukan menggunakan cabinet dryer dengan suhu 60 ${ }^{\circ} \mathrm{C}$ selama 6 jam untuk kacang kedelai hitam dan 5 jam untuk kacang komak. Kemudian kacang yang telah kering digiling menggunakan disc mill dan diayak menggunakan ayakan 10 mesh.

\section{Pembuatan Produk Food Bar}

Seluruh bahan disiapkan dan ditimbang terlebih dahulu sesuai dengan formula yang telah didapatkan. Grits kacang kedelai hitam dan grits kacang komak dicampur kemudian dilakukan penyangraian pada wajan selama 7 menit pada suhu $180^{\circ} \mathrm{C}$. Selama proses penyangraian berlangsung bahan margarin, madu, gula merah, dan pasta vanili dimasukkan secara berurutan ke dalam panci, lalu dipanaskan hingga mengental. Grits yang telah disangrai kemudian dicampur dengan binder (campurran madu, gula merah dan margarin) menggunakan spatula untuk selanjutnya dicetak $11 \times 4,4 \times 1 \mathrm{~cm}$ dalam loyang yang telah diolesi margarin. Kemudian pengovenan dilakukan menggunakan oven listrik selama 10 menit dengan suhu $120^{\circ} \mathrm{C}$. Selanjutnya cokelat susu blok dilelehkan dan dioleskan pada salah satu sisi secara merata serta didinginkan di dalam refrigerator (suhu $4{ }^{\circ} \mathrm{C}$ ) selama 10-15 menit.

\section{Rancangan Percobaan}

\section{Formulasi Linear Programming}

\section{Variabel keputusan}

Terdiri dari 6 variabel yang dibutuhkan untuk membuat formula food bar, yaitu:

$\mathrm{X}_{1}=$ grits kacang kedelai hitam $(\underline{\mathrm{kh}}) ; \mathrm{X}_{2}=$ grits kacang komak ( $\underline{\mathrm{k}}) ; \mathrm{X}_{3}=$ margarin $(\underline{\mathrm{mg}})$; $\mathrm{X}_{4}=\operatorname{madu}(\underline{\mathrm{md}}) ; \mathrm{X}_{5}=$ gula merah $(\mathrm{gm}) ; \mathrm{X}_{6}=$ cokelat susu batang (ㅁ)

\section{Fungsi tujuan}

Fungsi tujuan bersifat maksimal yaitu memaksimalkan kandungan kalori bahan baku sesuai dengan standar pemenuhan kalori food bar. Notasi $\mathrm{K}$ menunjukkan kandungan kalori pada setiap bahan.

$Z_{\text {maks }}=K_{\mathrm{kh}} X_{1}+K_{\mathrm{k}} X_{2}+K_{m g} X_{3}+K_{m d} X_{4}+$ $\mathrm{K}_{\mathrm{gm}} \mathrm{X}_{5}+\mathrm{K}_{\mathrm{c}} \mathrm{X}_{6}$

Keterangan $: \mathrm{K}_{\mathrm{kh}}=$ kalori kacang kedelai hitam; $\mathrm{K}_{\mathrm{k}}=$ kalori kacang komak; $\mathrm{K}_{\mathrm{mg}}=$ kalori margarin ; $\mathrm{K}_{\mathrm{md}}=$ kalori madu; $\mathrm{K}_{\mathrm{gm}}=$ kalori gula merah; $\mathrm{K}_{\mathrm{c}}=$ kalori cokelat

\section{Fungsi batasan}

Kadar karbohidrat

$\mathrm{K}_{\mathrm{kh}} \mathrm{X}_{1}+\mathrm{K}_{\mathrm{k}} \mathrm{X}_{2}+\mathrm{K}_{\mathrm{md}} \mathrm{X}_{4}+\mathrm{K}_{\mathrm{gm}} \mathrm{X}_{5}+\mathrm{K}_{\mathrm{cm}} \mathrm{X}_{6} \geq$ 0.48

$\mathrm{K}_{\mathrm{kh}} \mathrm{X}_{1}+\mathrm{K}_{\mathrm{k}} \mathrm{X}_{2}+\mathrm{K}_{\mathrm{md}} \mathrm{X}_{4}+\mathrm{K}_{\mathrm{gm}} \mathrm{X}_{5}+\mathrm{K}_{\mathrm{cm}} \mathrm{X}_{6} \leq$ 0.60

Kadar protein

$\mathrm{K}_{\mathrm{kh}} \mathrm{X}_{1}+\mathrm{K}_{\mathrm{k}} \mathrm{X}_{2}+\mathrm{K}_{\mathrm{gm}} \mathrm{X}_{5}+\mathrm{K}_{\mathrm{cm}} \mathrm{X}_{6} \geq 0.12$

$\mathrm{K}_{\mathrm{kh}} \mathrm{X}_{1}+\mathrm{K}_{\mathrm{k}} \mathrm{X}_{2}+\mathrm{K}_{\mathrm{gm}} \mathrm{X}_{5}+\mathrm{K}_{\mathrm{cm}} \mathrm{X}_{6} \leq 0.18$

Kadar lemak

$\mathrm{K}_{\mathrm{kh}} \mathrm{X}_{1}+\mathrm{K}_{\mathrm{k}} \mathrm{X}_{2}+\mathrm{K}_{\mathrm{mg}} \mathrm{X}_{3}+\mathrm{K}_{\mathrm{gm}} \mathrm{X}_{5}+\mathrm{K}_{\mathrm{cm}} \mathrm{X}_{6} \geq$ 0.19

$\mathrm{K}_{\mathrm{kh}} \mathrm{X}_{1}+\mathrm{K}_{\mathrm{k}} \mathrm{X}_{2}+\mathrm{K}_{\mathrm{mg}} \mathrm{X}_{3}+\mathrm{K}_{\mathrm{gm}} \mathrm{X}_{5}+\mathrm{K}_{\mathrm{cm}} \mathrm{X}_{6} \leq$ 0.24

Batasan bahan pengikat

$\mathrm{X}_{3}+\mathrm{X}_{4}+\mathrm{X}_{5}=0.33$

Penambahan yang terlalu sedikit menyebabkan pengikat tidak bisa mengikat grits, sehingga didapatkan food bar yang tidak kompak. Tabel 2 menunjukkan batasan bahan pengikat yang diharapkan mampu menghasilkan 3 formula dengan dominasi grits kacang komak, dominasi grits kacang kedelai hitam, dan seimbang. 
Tabel 2 Variasi batasan binder food bar

\begin{tabular}{lccc}
\hline \multicolumn{1}{c}{ Bahan pengikat } & Formula 1 (w/w \%) & Formula 2 (w/w \%) & Formula 3 (w/w\%) \\
\hline Madu & 11.0 & 13.0 & 11.8 \\
Gula merah & 11.0 & 12.0 & 11.8 \\
Margarin & 11.0 & 8.0 & 9.4 \\
\hline
\end{tabular}

Batasan cokelat susu batang

$\mathrm{X}_{6}=0.25$

Jika penambahan kurang dari $25 \%$ maka tidak dapat mengokohkan bentuk food bar. Jika penambahan lebih dari $25 \%$ maka akan dihasilkan rasa yang terlalu manis dan cokelat susu batang akan lebih mendominasi rasa food bar.

Batasan bahan baku

$\mathrm{X}_{1}+\mathrm{X}_{2}=0.42$

Berdasarkan basis formula, total proporsi bahan baku sebesar $40 \%$. Penambahan $2 \%$ merupakan alokasi proporsi vanili yang tidak menghasilkan kalori, dimana dalam jumlah tersebut bahan baku dapat terikat dengan baik. Perbandingan bahan baku untuk setiap formula dipecahkan oleh aplikasi POM-QM versi 3.0.

Jumlah total campuran sebesar $100 \%$

$X_{1}+X_{2}+X_{3}+X_{4}+X_{5}+X_{6}=1$

\section{Pengujian Tingkat Kenyang dan Uji Organoleptik}

Uji tingkat kenyang menggunakan pengukuran VAS (Visual Analogue Scale) unipolar tidak terstruktur. Panelis yang berpartisipasi pada uji ini berjumlah 31 orang. Panelis yang mengikuti uji termasuk ke dalam panelis tidak terlatih yang berasal dari lingkungan Universitas Brawijaya, Malang. Uji organoleptik dilakukan menggunakan Hedonic Scale Scoring. Metode uji organoleptik yang dilakukan adalah uji kesukaan untuk parameter warna, rasa, aroma, dan tekstur. Uji organoleptik dilakukan pada 40 orang yang termasuk kedalam panel konsumen di lingkungan FTP Universitas Brawijaya.

Blundell et al. (2010), memaparkan beberapa skala yang umum digunakan dalam pengujian kenyang adalah lapar (hunger), keinginan makan (desire to eat), penuh (fullness), dan kenyang (satiety). Pada penelitian Karalus (2011), sensasi kenyang (satiation) akan menghasilkan respon kepuasan (satisfaction), sedangkan sensasi lapar (hunger) akan menghasilkan respon keinginan makan (desire to eat). Adapun kriteria panelis yang dibutuhkan dalam penelitian ini:

1. Bersedia untuk mengikuti rangkaian uji sensoris;

2. Panelis tidak dalam paksaan untuk mengkonsumsi jenis sampel yang digunakan;

3. Panelis tidak memiliki alergi atau intoleransi terhadap sampel;

4. Panelis tidak sedang minum obat yang dapat menyebabkan reaksi merugikan;

5. Panelis tergolong dalam Indeks Massa Tubuh (IMT) normal.

Perekrutan panelis uji dilakukan dalam beberapa tahap. Berikut adalah tahapan penyeleksian panelis:

1. Pengisian kuisioner. Tahap pengisian kuisioner merupakan tahap awal sebelum pengujian utama. Pertanyaan yang diajukan berupa pertanyaan umum seperti nama, jenis kelamin, pekerjaan, umur, tinggi badan, berat badan, pertanyaan seputar food bar, dan kesediaan melakukan pengujian. Berat badan dan tinggi badan digunakan untuk menentukan IMT (Indeks Massa Tubuh) panelis.

2. Pengenalan produk. Tahap kedua merupakan tahap persiapan sebelum pengujian. Pada tahap ini dilakukan pencicipan food bar grits kacang komak dan kacang kedelai hitam. Pengenalan deskripsi sensasi kenyang dan lapar secara umum juga dilakukan. Penyajian food bar untuk pencicipan tidak disediakan dengan porsi penuh. Panelis diharapkan sudah mengenal sensasi kenyang dan lapar sebelum mengikuti pengujian.

3. Pengujian. Pada tahap pengujian tingkat kenyang, produk food bar disajikan sebanyak 1 porsi (50 gram) per formula. 
Terdapat 3 formula food bar yang diujikan pada hari yang berbeda. Variabel respon yang digunakan pada pengujian adalah lapar (hunger), keinginan makan (desire to eat), kenyang (satiation), dan kepuasan (satisfaction).

\section{Prosedur Analisis}

Analisa yang dilakukan pada grits kacang kedelai hitam, grits kacang komak, dan food bar meliputi: Kadar air metode oven kering (AOAC, 2005), kadar abu (AOAC, 2005), kadar lemak dengan Soxhlet (AOAC, 2005), kadar protein metode Kjedahl (AOAC, 2005), kadar karbohidrat (By Different) (AOAC, 1995), total kalori (Kusumastuty et al., 2015), kadar serat kasar (AOAC, 2005), warna dengan color reader (Yuwono dan Susanto, 1998), dan analisa daya patah dengan Texture Analyzer (Yuwono dan Susanto, 1998).

\section{Analisis data}

Formulasi food bar metode linear programming menggunakan aplikasi POMQM versi 3.0. Pada uji tingkat kenyang, aplikasi analisa data yang digunakan adalah Statistical Software Minitab 17. Pengujian yang dipilih adalah Friedman test yang bertujuan untuk mengetahui respon tingkat kenyang dan tingkat kesukaan food bar. Uji beda pada tingkat kenyang yang digunakan adalah Wilcoxon signed rank test. Hubungan antar variabel respon kenyang menggunakan regresi non linear dan spearman rho. Pemilihan formulasi terbaik pada karakteristik kimia dan tingkat kenyang menggunakan Ms. Excel 2010 metode multiple attribute. Penentuan formulasi terbaik pada tingkat kesukaan menggunakan metode Indeks Efektivitas (De Garmo et al., 1984). Data fisikokimia yang diperoleh dianalisa menggunakan ANOVA (Analysis of Variance) dilanjutkan dengan Fisher Test pada program Minitab 17.

\section{HASIL DAN PEMBAHASAN}

\section{Kandungan Nutrisi Bahan Baku}

Bahan-bahan yang digunakan dalam pembuatan food bar antara lain grits kacang kedelai hitam, grits kacang komak, margarin, madu, gula merah, cokelat susu blok, dan pasta vanili. Kandungan nutrisi tiap bahan baku penting diketahui untuk menentukan formulasi food bar sehingga didapatkan produk yang sesuai dengan standar Emergency Food Product.

Tabel 3 Hasil analisis kimia grits kacang komak

\begin{tabular}{lcc}
\hline \multicolumn{1}{c}{ Komponen } & Grits Kacang Komak & Biji kacang komak* \\
\hline Kadar air $(\%)$ & $11.77 \pm 0.09$ & $8.47 \pm 0.52$ \\
Kadar abu (\%) & $3.63 \pm 0.07$ & $3.50 \pm 0.07$ \\
Kadar protein $(\%)$ & $32.38 \pm 0.94$ & $23.95 \pm 0.15$ \\
Kadar lemak $(\%)$ & $1.72 \pm 0.07$ & $1.02 \pm 0.06$ \\
Kadar karbohidrat by different $(\%)$ & $50.58 \pm 1.01$ & $61.86 \pm 0.70$ \\
Total kalori (kkal/100 g) & 367.16 & 352.40 \\
\hline
\end{tabular}

Keterangan: *)Sumber pustaka kacang komak: Hossein et al., (2016)

Tabel 4 Hasil analisis kimia grits kacang kedelai hitam

\begin{tabular}{lcc}
\hline \multicolumn{1}{c}{ Komponen } & Grits Kedelai Hitam & Biji kedelai hitam* \\
\hline Kadar air (\%) & $8.85 \pm 0.06$ & 10.84 \\
Kadar abu (\%) & $5.15 \pm 0.23$ & 5.81 \\
Kadar protein (\%) & $39.94 \pm 0.42$ & 36.50 \\
Kadar lemak (\%) & $16.38 \pm 0.17$ & 14.59 \\
Kadar karbohidrat by different $(\%)$ & $29.69 \pm 0.38$ & 43.11 \\
Total kalori (kkal/100 g) & 425.94 & 449.75 \\
\hline
\end{tabular}

Keterangan: *) Sumber pustaka kacang kedelai hitam: Putri dkk., (2016) 
Tabel 5 Hasil Perhitungan Kalori Bahan Baku

\begin{tabular}{lcccc}
\hline \multicolumn{1}{c}{ Bahan Baku } & Protein (\%) & Lemak (\%) & Karbohidrat (\%) & Kalori (kkal) \\
\hline Grits kacang kedelai hitam & 39.94 & 16.38 & 29.69 & 425.94 \\
Grits kacang komak & 32.38 & 1.72 & 50.58 & 347.32 \\
Margarin $^{* *}$ & - & 77.78 & - & 700 \\
Madu** $^{* *}$ & - & - & 77.60 & 310.4 \\
Cokelat susu blok $^{* *}$ & 4 & 44 & 52 & 620 \\
Gula merah *** & 3 & 10 & 76 & 406 \\
\hline
\end{tabular}

Keterangan : *) Hasil Analisa

**) Terdapat dalam label kemasan masing-masing bahan

***) Heryani (2016)

\section{Penyelesaian Model Matematis}

Model matematis dalam penelitian ini diselesaikan menggunakan metode linear programming dengan bantuan perangkat lunak POM-QM untuk windows versi 3.0. Formula food bar tersusun dari enam bahan baku, yaitu grits kacang kedelai hitam $\left(\mathrm{X}_{1}\right)$, grits kacang komak $\left(\mathrm{X}_{2}\right)$, margarin $\left(\mathrm{X}_{3}\right)$, madu $\left(\mathrm{X}_{4}\right)$, gula merah $\left(\mathrm{X}_{5}\right)$, dan cokelat susu blok $\left(\mathrm{X}_{6}\right)$. Model matematis formulasi food bar sebagai berikut :

\section{Fungsi Tujuan:}

Maksimasi: $\mathrm{Zmaks}=425.94 \mathrm{X}_{1}+34732 \mathrm{X}_{2}+$ $700 X_{3}+310.4 X_{4}+406 X_{5}+620 X_{6}$

\section{Fungsi Batasan:}

Kadar karbohidrat

$0.2969 X_{1}+0.5058 X_{2}+0.776 X_{4}+0.76 X_{5}+$ $0.52 \mathrm{X}_{6} \geq 0.48$

$0.2969 \mathrm{X}_{1}+0.5058 \mathrm{X}_{2}+0.776 \mathrm{X}_{4}+0.76 \mathrm{X}_{5}+$

$0.52 \mathrm{X}_{6} \leq 0.60$

Kadar protein

$0.3994 X_{1}+0.3238 X_{2}+0.03 X_{5}+0.04 X_{6} \geq$

0.12

$0.3994 X_{1}+0.3238 X_{2}+0.03 X_{5}+0.04 X_{6} \leq$ 0.18

Kadar lemak

$0.1638 \mathrm{X}_{1}+0.0172 \mathrm{X}_{2}+0.7778 \mathrm{X}_{3}+0.1 \mathrm{X}_{5}+$ $0.44 \mathrm{X}_{6} \geq 0.19$

$0.1638 \mathrm{X}_{1}+0.0172 \mathrm{X}_{2}+0.7778 \mathrm{X}_{3}+0.1 \mathrm{X}_{5}+$ $0.44 \mathrm{X}_{6} \leq 0.24$

Batasan pengikat

$\mathrm{X}_{3}+\mathrm{X}_{4}+\mathrm{X}_{5}=0.33$
$\mathrm{X}_{3}(\mathrm{~F} 1)=0.11 ;(\mathrm{F} 2)=0.08 ;(\mathrm{F} 3)=0.094$

$\mathrm{X}_{4}(\mathrm{~F} 1)=0.11 ;(\mathrm{F} 2)=0.13 ;(\mathrm{F} 3)=0.118$

$\mathrm{X}_{5}(\mathrm{~F} 1)=0.11 ;(\mathrm{F} 2)=0.12 ;(\mathrm{F} 3)=0.118$

Bahan pengikat merupakan titik kritis pada pembuatan food bar. Jika jumlahnya kurang atau lebih dari 0.33 maka akan sulit mengikat grits kacang. Formula 1 merupakan jumlah dasar pada penelitian pendahuluan. Pada formula 2 dan 3, batasan bahan pengikat yang digunakan telah divariasikan. Hasil variasi tersebut mempertimbangkan kedekatan jumah kalori setiap formula serta kenampakan fisik dan sensoris ketika menjadi produk.

Batasan cokelat susu batang

$\mathrm{X}_{6}=0.25$

Batasan bahan baku

$\mathrm{X}_{1}+\mathrm{X}_{2}=0.42$

Jumlah total campuran sebesar $100 \%$

$X_{1}+X_{2}+X_{3}+X_{4}+X_{5}+X_{6}=1$

Jumlah kalori tiap bahan dan model matematis yang telah diperoleh kemudian dimasukkan datanya ke dalam aplikasi POMQM versi 3.0. Tabel 6 menunjukkan jumlah bahan yang harus ditambahkan disertai kalori yang akan dihasilkan untuk ketiga formula. Jumlah bahan baku yang ditambahkan telah sesuai dengan hasil formula yang diharapkan yaitu pada formula 1 didominasi grits kacang komak, formula 2 didominasi grits kacang kedelai hitam, dan formula 3 memiliki perbandingan grits kacang seimbang. 
Tabel 6 Formulasi food bar hasil perhitungan linear programming

\begin{tabular}{lccc}
\hline \multirow{2}{*}{ Bahan baku } & \multicolumn{3}{c}{ Jumlah $(\%)$} \\
\cline { 2 - 4 } & Formula 1 & Formula 2 & Formula 3 \\
\hline Grits kacang komak & 26.97 & 15.90 & 20.91 \\
Grits kedelai hitam & 15.03 & 26.10 & 21.09 \\
Madu & 11.00 & 13.00 & 11.80 \\
Gula merah & 11.00 & 12.00 & 11.80 \\
Margarin & 11.00 & 8.00 & 9.40 \\
Cokelat susu batang & 25.00 & 25.00 & 25.00 \\
Kalori (kkal/100 g) & 468.49 & 466.46 & 467.65 \\
Kalori (kkal/50 g) & 234.25 & 233.23 & 233.85 \\
\hline
\end{tabular}

\section{Karakteristik Kimia Food bar}

Berdasarkan Tabel 7, kadar air ketiga formula tidak berbeda nyata karena $\mathrm{p}$-value $>0.05$ (p-value $=0.964$ ) dan telah memenuhi standar persyaratan food bar yaitu kurang dari 9.5\%. Kadar abu pada Tabel 7. menunjukkan hasil yang tidak berbeda nyata karena p-value >0.05 (p-value $=0.513)$. Kadar abu secara kasar menggambarkan kandungan mineral yang terdapat dalam suatu bahan pangan (Mayasari, 2010).

Kadar protein yang dihasilkan ketiga formula food bar berbeda nyata karena $\mathrm{p}$ value $<0,05$ ( $\mathrm{p}$-value $=0,000)$. Hasil uji lanjut fisher menunjukkan bahwa formula 1 berbeda dengan formula 2 dan kedua formula tersebut berbeda dengan formula 3 . Formula 2 memiliki rerata tertinggi kadar protein sebesar $13.07 \%$. Proporsi kacang pada formula 2 memiliki persentase grits kacang kedelai hitam yang lebih tinggi dimana kandungan proteinnya mencapai $39.94 \%$, sedangkan kacang komak hanya $32.38 \%$.
Kadar lemak ketiga formula food bar tidak berbeda nyata karena $\mathrm{p}$-value $>0.05$ ( $\mathrm{p}$-value $=0,564$ ). Ketiga formula telah memenuhi rekomendasi standar persyaratan food bar yaitu berada pada rentang 19-24\%.

Kadar karbohidrat food bar yang dihasilkan berdasarkan Tabel 7, berbeda nyata untuk ketiga formula karena $\mathrm{p}$ value $<0.05$ ( $\mathrm{p}$-value $=0.024)$. Formula 1 memiliki kadar karbohidrat tertinggi yaitu $63.01 \%$. Pada formula 1, persentase grits kacang komak lebih besar daripada grits kacang kedelai hitam. Grits kacang komak mengandung $50.58 \%$ karbohidrat. Sumbangsih karbohidrat juga berasal dari binder yang terdiri dari madu dan gula merah. Uji lanjut fisher menunjukkan formula 1 dan 3 tidak berbeda, namun keduanya berbeda dengan formula 2 . Formula 1 memenuhi rekomendasi standar persyaratan food bar yaitu berkisar antara 48$60 \%$.

Tabel 7 Data rerata hasil analisis kimia food bar

\begin{tabular}{lcccc}
\hline \multirow{2}{*}{ Komponen } & \multicolumn{3}{c}{ Formula } & \multirow{2}{*}{ Standar (\%) } \\
\cline { 2 - 4 } & Formula 1 & Formula 2 & Formula 3 & \\
\hline Kadar Air (\%) & $7.29 \pm 0.23 \mathrm{a}$ & $7.18 \pm 0.51 \mathrm{a}$ & $7.35 \pm 0.28 \mathrm{a}$ & $<9.5$ \\
Kadar Abu (\%) & $2.46 \pm 0.15 \mathrm{a}$ & $2.67 \pm 0.14 \mathrm{a}$ & $2.46 \pm 0.24 \mathrm{a}$ & - \\
Kadar Protein (\%) & $7.84 \pm 0.49 \mathrm{c}$ & $13.07 \pm 0.36 \mathrm{a}$ & $8.74 \pm 0.48 \mathrm{~b}$ & $12-18$ \\
Kadar Lemak (\%) & $19.40 \pm 0.34 \mathrm{a}$ & $19.00 \pm 0.04 \mathrm{a}$ & $19.11 \pm 0.39 \mathrm{a}$ & $19-24$ \\
Kadar Karbohidrat & $63.01 \pm 1.06 \mathrm{a}$ & $58.08 \pm 0.33 \mathrm{~b}$ & $62.34 \pm 1.25 \mathrm{a}$ & $48-60$ \\
by different (\%) & $5.09 \pm 0.30 \mathrm{a}$ & $3.14 \pm 0.11 \mathrm{~b}$ & $3.55 \pm 0.14 \mathrm{~b}$ & - \\
Kadar Serat kasar & $457.97 \pm 1.08 \mathrm{a}$ & $455.60 \pm 2.21 \mathrm{a}$ & $456,33 \pm 0,44 \mathrm{a}$ & - \\
Kalori (kkal/100 g) & $228.98 \pm 0.54 \mathrm{a}$ & $227.80 \pm 1.11 \mathrm{a}$ & $228,16 \pm 0,22 \mathrm{a}$ & $233-250$ \\
Kalori (kkal/50 g) & & & & \\
\hline
\end{tabular}

Keterangan: a) Data disajikan sebagai rerata \pm SE

b) Nilai yang diikuti huruf beda menunjukkan beda nyata $(\mathrm{P}>0,05)$

c) Standar berdasarkan Zoumas et al., (2002) 
Kadar serat kasar berbeda nyata untuk ketiga formula karena p-value $<0.05$ ( $\mathrm{p}$-value $=0.006$ ). Uji lanjut fisher menunjukkan formula 1 berbeda dengan formula 2 dan formula 3. Formula 1 memiliki rerata kadar serat kasar tertinggi sebesar $5.089 \%$. Berdasarkan persentase bahan baku, formula 1 memiliki jumlah kacang komak yang lebih tinggi. Kandungan serat kasar pada kacang komak dapat mencapai $10.20 \%$ (Ragab et al., 2015), sedangkan kacang kedelai hitam sebesar $5.57 \%$ (Pertiwi et al., 2014). Kalori yang dihasilkan oleh ketiga formula food bar pada Tabel 7 tidak berbeda nyata karena pvalue $>0.05$ ( $\mathrm{p}$-value $=0.593$ ). Rerata kalori food bar menunjukkan jumlah kalori berada pada kisaran angka 227.80-228.98 kkal. Kalori hasil perhitungan aplikasi linear programming yaitu 234.81-236.92 kkal/50 g, nilai tersebut mengacu pada standar food bar sebagai pangan darurat yaitu sebesar 233-250 $\mathrm{kkal} / 50 \mathrm{~g}$.
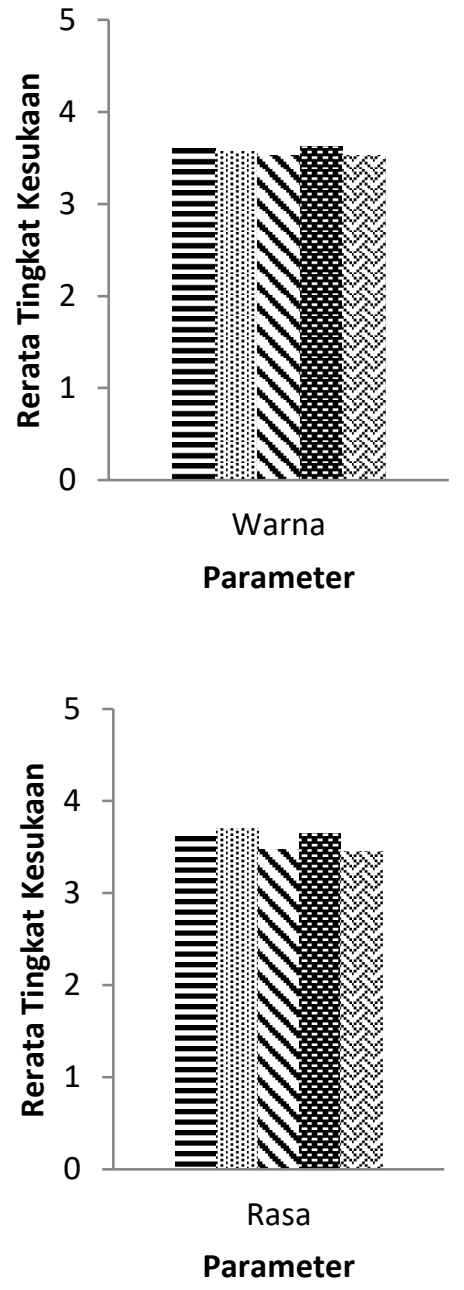

Berdasarkan Tabel 7 didapatkan hasil pengujian kimia yang paling memenuhi rekomendasi standar persyaratan food bar adalah formula 2, dengan persentase didominasi oleh grits kacang kedelai hitam. Hasil yang didapatkan yaitu $7.18 \%$ air, $13.07 \%$ protein, $19.00 \%$ lemak, dan $58.08 \%$ karbohidrat. Namun formula 2 memiliki kalori yang paling rendah diantara kedua formula lainnya, yaitu sebesar $227.80 \mathrm{kkal} / 50$ g.

\section{Hasil Uji Organoleptik Food Bar}

Uji organoleptik dilakukan dengan menggunakan Hedonic Scale Scoring terhadap parameter warna, aroma, rasa, dan tekstur dari produk food bar. Panelis pada penelitian ini adalah 40 mahasiswa FTP Universitas Brawijaya dengan rentang usia 16-31 tahun. Hasil penilaian panelis terhadap food bar diilustrasikan pada Gambar 1.
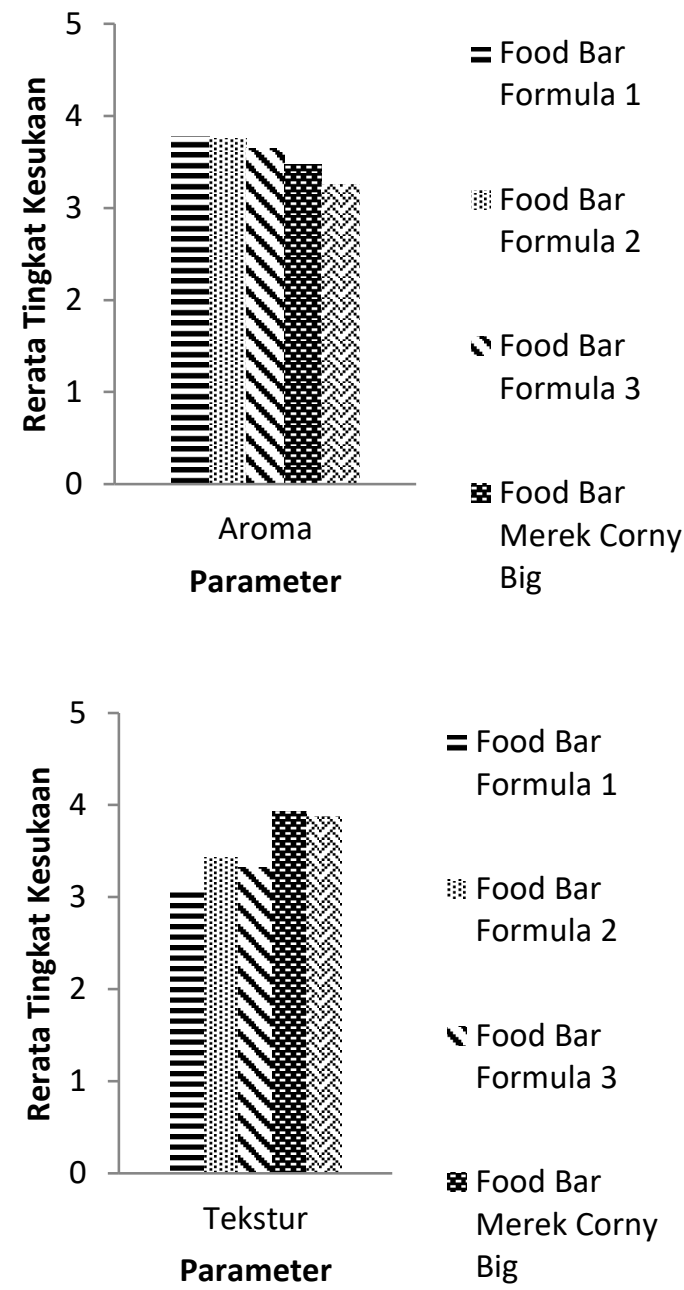

Gambar 1 Hasil Uji Organoleptik Food Bar 
Hasil uji hedonik food bar formula 1 meliputi warna suka (3.60), aroma suka (3.78), rasa suka (3.65), dan tekstur biasa (3.05). Formula 2 meliputi warna suka (3.58), aroma suka (3.75), rasa suka (3.70), dan tekstur biasa (3.43). Formula 3 meliputi warna suka (3.53), aroma suka (3.65), rasa biasa (3.48), dan tekstur biasa (3.33). Corny Big meliputi warna suka (3.63), aroma biasa (3.48), rasa suka (3.65), dan tekstur suka (3.93). Fitbar meliputi warna suka (3.53), aroma biasa (3.25), rasa biasa (3.45), dan tekstur suka (3.88). Hasil Friedman Test menunjukkan tidak ada perbedaan antara food bar formulasi dengan komersial pada parameter warna, aroma, dan rasa, sedangkan parameter tekstur terdapat perbedaan. Food bar dengan bahan baku tepung cenderung tidak memberikan perbedaaan seperti pada penelitian food bar tepung kacang kedelai dan kacang hijau (Fajri et al., 2013) dan food bar dari tepung millet putih dan kacang merah (Anandito et al., 2016), diduga perbedaan tersebut muncul karena bentuk bahan baku yang tidak seragam yaitu berupa gilingan kacang dengan ukuran $\leq 10$ mesh.
Menurut Kusumastuty et al. (2015), tekstur food bar dipengaruhi oleh bahan dasar, ketebalan cetakan dan suhu oven yang terlalu tinggi. Penambahan madu dapat menghasilakn tekstur food bar yang mudah digigit.

\section{Hasil Uji Tingkat Kenyang}

Pengujian tingkat kenyang pada tiga formula food bar menghasilkan empat variabel respon yaitu kenyang akhir, lapar, keinginan makan, dan kepuasaan, sedangkan penambahan kenyang merupakan selisih dari kenyang akhir dan status lapar.

Pengujian dilakukan menggunakan VAS (Visual Analogue Scale) tidak terstruktur sepanjang $10 \mathrm{~cm}$. Menurut Blundell et al. (2010), desain skala dasar yang digunakan untuk melaporkan perasaan terkait nafsu makan mencakup garis terstruktur dan tidak terstruktur uni dan bipolar, kategori verbal, dan penilaian numerik. Metode yang paling umum digunakan adalah garis tidak terstruktur unipolar. Tabel 8 menunjukkan variabel respon dari pengujian tingkat kenyang

Tabel 8 Variabel respon tingkat kenyang food bar

\begin{tabular}{lcccc}
\hline \multicolumn{1}{c}{ Variabel } & Formula & Rata-rata & p-value & Keterangan \\
\hline \multirow{2}{*}{ Kenyang akhir } & 1 & $6.40 \pm 0.28$ & & \\
& 2 & $6.65 \pm 0.25$ & 0.798 & Tidak beda nyata \\
Lapar & 3 & $6.85 \pm 0.27$ & & \\
& 1 & $6.31 \pm 0.32$ & & Tidak beda nyata \\
Keinginan & 2 & $7.29 \pm 0.28$ & 0.108 & \\
makan & 3 & $6.93 \pm 0.29$ & & Beda nyata \\
& 1 & $6.64 \pm 0.35$ & & \\
Kepuasan & 2 & $5.18 \pm 0.33$ & 0.002 & Tidak Beda nyata \\
& 1 & $6.11 \pm 0.40$ & & \\
\hline
\end{tabular}

Keterangan: a) Data disajikan sebagai rerata $\pm \mathrm{SE}$

b) Beda nyata jika p-value $<0,05$

c) Rata-rata mendekati 10 menunjukkan respon semakin besar

Berdasarkan Tabel 8, semakin besar skala rata-rata (mendekati skala 10) pada variabel respon maka semakin besar pula respon kenyang akhir, lapar, keinginan makan dan kepuasan yang diberikan. Jika semakin kecil skala (menjauhi skala 10), maka respon yang diberikan pun semakin kecil. Pada variabel kenyang akhir, formula 3 memberikan rasa kenyang yang paling besar (6.85) namun jika dibandingkan dengan ketiga formula, hasilnya tidak berbeda nyata karena p-value $>0.05 \quad$ (p-value $=0.798)$. Perbedaan respon kenyang pada ketiga formula food bar sangat kecil sehingga dihasilkan nilai skala yang tidak beda nyata. Pada variabel kepuasan berdasarkan Tabel 8, 
formula yang 3 juga menghasilkan nilai yang paling besar (6.94) namun ketiga formula food bar menunjukkan hasil yang tidak berbeda nyata karena p-value $=0.050$. Perbedaan kepuasan cukup tipis diantara ketiga formula karena memang memiliki komposisi dan rasa yang tidak jauh berbeda.

Keadaan lapar dari panelis paling besar pada saat pengujian di formula 2 yaitu 7.29, namun dari ketiga formula dihasilkan p-value yang tidak berbeda nyata karena pvalue $>0.05$ ( $\mathrm{p}$-value $=0.108)$. Pada tingkat keinginan makan panelis paling besar terlihat pada formula 1 yaitu sebesar 6.64. Ketiga formula tersebut dinyatakan berbeda nyata karena $\quad \mathrm{p}$-value $<0.05 \quad(\mathrm{p}$-value $=0.002)$ sehingga perlu dilakukan uji beda menggunakan Wilcoxon sign ranked.

Berdasarkan Tabel 9, perbedaan antar formula dilihat dari nilai sig., jika kurang dari 0.05 maka dinyatakan berbeda, namun jika lebih besar dari 0.05 dinyatakan sama. Notasi yang akan dimunculkan pada formula 1 dan formula 3 akan sama namun berbeda dengan formula 2 .

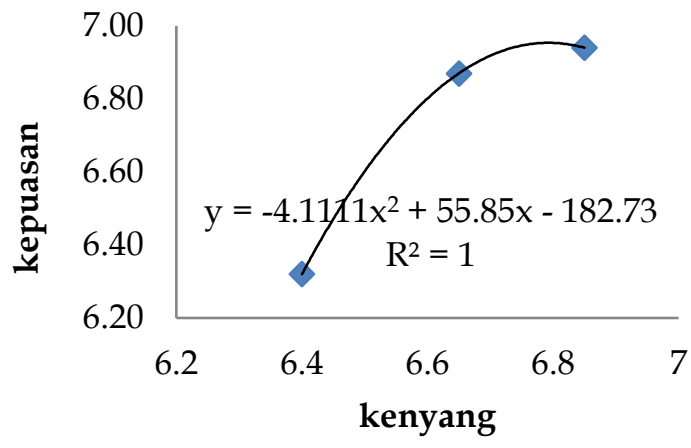

Gambar 2 Hubungan antara kenyang dengan kepuasan

Gambar 2 menunjukkan bahwa sensasi kenyang memberikan pengaruh terhadap kepuasan panelis. Hal tersebut dapat dilihat pada koefisien determinasi yang bernilai 1. Nilai koefisien determinasi menunjukkan tingkat signifikansi atau kesesuaian hubungan antara variabel $\mathrm{X}$ dan variabel Y (Sinambela et al., 2016). Selain itu, garis lengkung dan persamaan yang dihasilkan menunjukkan hubungan tidak linear model kuadratik. Hubungan antara dua peubah yang terdiri dari variabel dependen (Y) dan variabel independen (X) akan memperoleh suatu kurva yang membentuk garis lengkung menaik atau menurun (Yusnandar, 2004). Perubahan pada respon kepuasan diikuti dengan perubahan yang tidak tetap pada respon kenyang.

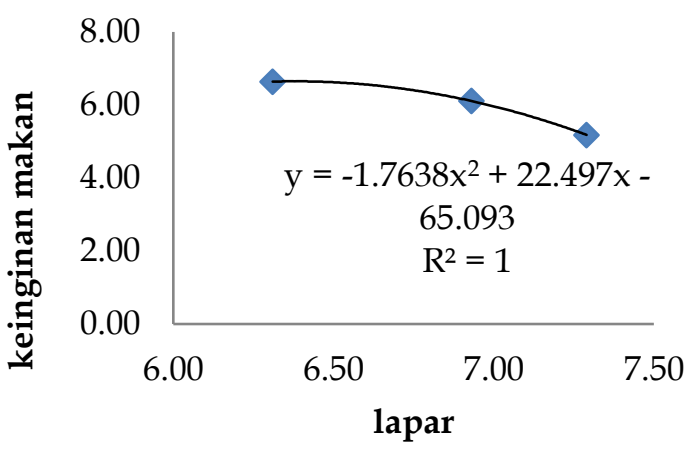

Gambar 3 Hubungan antara keinginan makan dengan lapar

Pada Gambar 3, dapat diketahui bahwa lapar memberikan pengaruh terhadap keinginan makan panelis. Hal tersebut dilihat dari koefisien determinasi yang bernilai 1 . Garis melengkung dan persamaan yang dihasilkan menunjukkan hubungan yang tidak linear model kuadratik. Perubahan pada respon keinginan makan diikuti dengan perubahan yang tidak tetap pada respon lapar.

Selain keempat variabel, terdapat pula variabel yang berasal dari selisih antara kenyang akhir dan lapar yaitu adalah penambahan (indeks) kenyang. Variabel ini bertujuan untuk memperjelas tingkat kenyang yang dihasilkan oleh ketiga formula food bar. Selain itu, kondisi lapar yang dirasakan oleh tiap individu berbeda beda walaupun pada akhirnya dapat memberikan efek kenyang yang hampir sama.

Tabel 9 Hasil uji Wilcoxcon signed ranks keinginan makan

\begin{tabular}{ccll}
\hline Variabel & Formula & Sig. & \multicolumn{1}{c}{ Ket. } \\
\hline \multirow{3}{*}{ Keinginan untuk makan } & F1 : F2 & 0.000 & Berbeda \\
& F1 : F3 & 0.474 & Sama \\
& F2 : F3 & 0.034 & Berbeda \\
\hline
\end{tabular}

Keterangan: Beda nyata jika p-value $<0.05$ 
Tabel 10 Variabel respon penambahan kenyang

\begin{tabular}{ccccc}
\hline Variabel & Formula & Rerata & p-value & Keterangan \\
\hline \multirow{3}{*}{ Penambahan kenyang } & 1 & $2.71 \pm 0.36$ & & \\
& 2 & $3.95 \pm 0.35$ & 0.003 & Beda nyata \\
\hline
\end{tabular}

Keterangan: a) Data disajikan sebagai rerata \pm SE

b) Beda nyata jika p-value $<0.05$

c) Rata-rata semakin besar, penambahan kenyang semakin besar

Tabel 11 Hasil uji Wilcoxon Signed Ranks Indeks Kenyang

\begin{tabular}{cccc}
\hline Variabel & Formula & Sig. & Ket. \\
\hline \multirow{3}{*}{ Penambahan kenyang } & F1 $:$ F2 & 0.008 & Berbeda \\
& F1 F3 & 0.013 & Berbeda \\
& F2 $:$ F3 & 0.729 & Sama \\
\hline
\end{tabular}

Keterangan: Beda nyata jika p-value $<0.05$

Berdasarkan Tabel 10, penambahan kenyang food bar yang dihasilkan berbeda nyata karena p-value $<0.005$ ( $\mathrm{p}$-value $=0.003$ ). Formula 2 memiliki rerata penambahan kenyang tertinggi. Penambahan kenyang dilakukan uji beda menggunakan Wilcoxon Signed Ranks.

Pada Tabel 11, perbedaan formula dilihat dari nilai sig., jika kurang dari 0.05 maka dinyatakan berbeda, namun jika lebih besar dari 0.05 dinyatakan sama. Pada formula 2 dibandingkan dengan formula 3 didapatkan nilai sig. lebih besar dari 0.05. Maka notasi yang akan dimunculkan pada formula 2 dan formula 3 akan sama namun keduanya berbeda dengan formula 1 . Formula 1 memiliki kandungan grits kacang komak lebih banyak dan kadar protein yang lebih kecil diantara ketiga formula.

Penambahan kenyang yang merupakan selisih respon kenyang dengan respon lapar dihubungkan dengan respon keinginan makan dan kepuasan. Hubungan diantaranya ditunjukkan pada Gambar 4 dan Gambar 5.

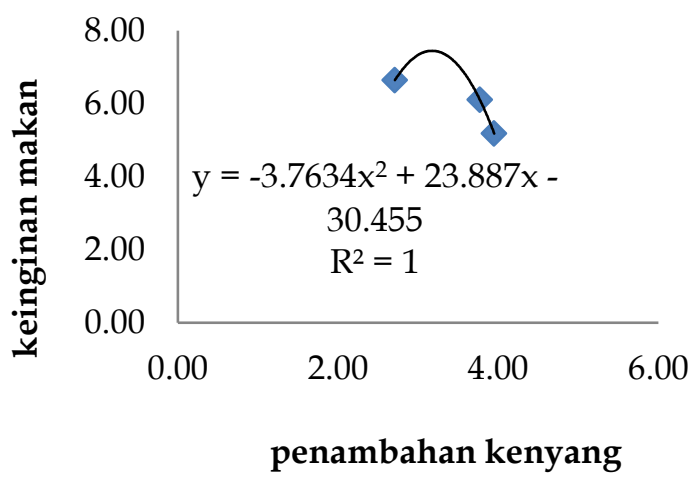

Gambar 4 Hubungan antara penambahan kenyang dan keinginan makan

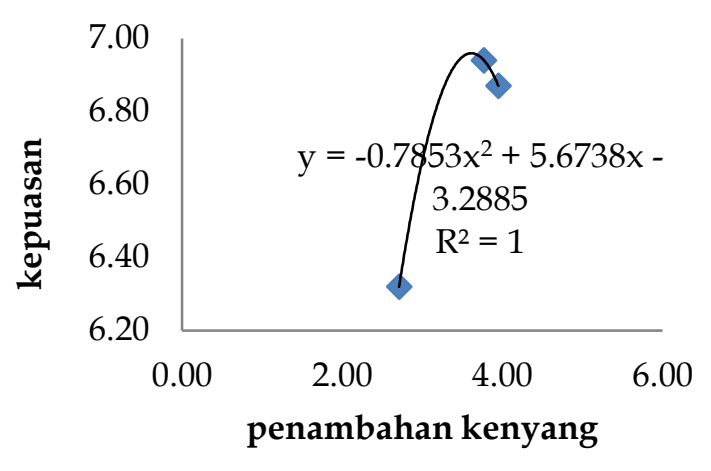

Gambar 5 Hubungan antara penambahan kenyang dan kepuasan

Pada Gambar 4 dan Gambar 5 dapat diketahui bahwa keinginan makan dan kepuasan panelis dipengaruhi oleh penambahan kenyang. Hubungan tersebut dapat dilihat pada koefisien determinasi yang bernilai 1. Garis lengkung dan persamaan pada gambar menunjukkan hubungan yang tidak linear model kuadratik. 
Korelasi Variabel Respon Kenyang dengan Makronutrien

Tabel 12 Hubungan makronutrien dan respon kenyang

\begin{tabular}{lcccc}
\hline \multicolumn{1}{c}{ Makro nutrien } & Spearman rho & Sig. & Nilai kritis & $\Sigma$ panelis \\
\hline Protein & 0.254 & 0.018 & & \\
Lemak & -0.245 & 0.018 & & \\
Karbohidrat & -0.245 & 0.018 & 0.356 & 31 orang \\
Kalori & -0.245 & 0.018 & & \\
Serat & -0.245 & 0.018 & & \\
\hline
\end{tabular}

Keterangan: a) nilai sig. $<0.05$ menunjukkan terdapat hubungan

b) tanda negatif menunjukkan hubungan yang negatif

Berdasarkan Tabel 12, terdapat hubungan yang positif antara penambahan kenyang dengan protein karena sig. $<0.05$ (sig.=0.018). Namun hasil koefisien korelasi $(\mathrm{r}=0.254)$ lebih kecil daripada $\mathrm{r}$ tabel $(0.356)$ (Zar, 1972) sehingga korelasi tidak signifikan. Namun, jika ditinjau dari hirarki makronutrien yang menimbulkan kenyang, secara berurutan yang paling meningkatkan kenyang adalah protein, karbohidrat dan lemak (Gerstein, 2004). Kadar karbohidrat, lemak, serat, dan kalori yang dihubungkan dengan penambahan kenyang pada Tabel 12 dinyatakan berkorelasi negatif karena sig.<0.05 (sig.=0.018). Nilai koefisien korelasi yang didapatkan adalah -0.245 . Nilai tersebut lebih kecil dari nilai kritis, sehingga hubungan diantaranya tidak signifikan.

\section{Penentuan Formula Terbaik}

\section{Berdasarkan Parameter Kimia dan Tingkat Kenyang}

Metode yang digunakan dalam pemilihan formula terbaik adalah multiple attribute (Zeleny, 1982). Penentuan formula dipilih berdasarkan standar persyaratan rekomendasi food bar dan variabel respon kenyang yang berpengaruh terhadap tingkat kekenyangan food bar. Parameter yang berperan dalam penentuan formula terbaik adalah respon kenyang, respon lapar, respon keinginan makan, respon kepuasan, dan respon indeks (penambahan) kenyang, kadar protein, kadar karbohidrat, kadar lemak, kadar serat, dan kalori.

Formulasi terbaik didapatkan oleh formula 2, selanjutnya formula 3 dan yang terakhir adalah formula 1. Pada formula 2, persentase kacang kedelai lebih mendominasi daripada persentase kacang komak yaitu masing-masing $26.1 \%$ dan $15.9 \%$. Selain itu, kandungan bahan lain yaitu $8 \%$ margarin, $13 \%$ madu, dan $12 \%$ gula merah. Formula 1 didominasi kacang komak dan formula 3 memiliki persentase yang seimbang diantara keduanya.

\section{Berdasarkan Tingkat Kesukaan Food Bar}

Penentuan perlakuan terbaik food bar menggunakan metode indeks efektifitas. Penentuan perlakuan terbaik dihitung berdasarkan hasil uji organoleptik (uji kesukaan) dan pemberian bobot nilai pada atribut/parameter produk. Atribut produk yang dianalisis dalam penentuan perlakuan terbaik food bar meliputi warna, aroma, rasa, dan tekstur.

Food bar formula 2 merupakan food bar dengan formula/perlakuan terbaik dengan proporsi bahan baku grits kacang kedelai hitam $26.10 \%$; grits kacang komak $15.90 \%$; margarin $8 \%$; madu 13\%; gula merah $12 \%$; dan cokelat susu blok 25\%. Tabel 13 menunjukkan karakteristik kimia, tingkat kenyang dan tingkat kesukaan formula terbaik. 
Tabel 13 Karakteristik kimia, tingkat kenyang dan tingkat kesukaan food bar formula terbaik

\begin{tabular}{lc}
\hline Karakteristik kimia & Jumlah \\
\hline Kadar air $(\%)$ & $7.18 \pm 0.51$ \\
Kadar abu (\%) & $2.67 \pm 0.14$ \\
Kadar protein $(\%)$ & $13.07 \pm 0.36$ \\
Kadar lemak (\%) & $19.00 \pm 0.04$ \\
Kadar karbohidrat $(\%)$ & $58.080 \pm 0.33$ \\
Kadar serat $(\%)$ & $3.14 \pm 0.11$ \\
Kalori (kkal/50 g) & $227.80 \pm 1.11$ \\
\hline Karakteristik tingkat kenyang & Jumlah \\
\hline Rasa kenyang panelis & $6.65 \pm 0.25$ \\
Rasa lapar panelis & $7.29 \pm 0.28$ \\
Keinginan untuk makan & $5.18 \pm 0.33$ \\
Kepuasan & $6.87 \pm 0.23$ \\
Indeks (penambahan) kenyang & $3.95 \pm 0.35$ \\
\hline Karakteristik tingkat kesukaan & Jumlah \\
\hline Warna & 3.575 \\
Aroma & 3.750 \\
Rasa & 3.700 \\
Tektur & 3.425 \\
\hline
\end{tabular}

\section{Karakteristik Fisik Food Bar Formulasi terbaik \\ Warna}

Warna produk food bar formula 2 dan food bar komersial diukur menggunakan color reader dengan parameter yang dibaca adalah ( $\left.\mathrm{L}^{*}\right)$ menyatakan tingkat kecerahan atau gelap terang produk yang diukur, $\left(\mathrm{a}^{*}\right)$ menyatakan nilai kemerahan, dan $\left(b^{*}\right)$ menyatakan nilai kekuningan. Hasil pengamatan warna food bar disajikan pada Tabel 14.

Berdasarkan Tabel 14 diketahui tingkat kecerahan $\left(\mathrm{L}^{*}\right)$ dan tingkat kekuningan $(\mathrm{b}+)$ ketiga food bar berbeda sangat nyata pada tingkat kepercayaan 99\%. Sedangkan tingkat kemerahan $(\mathrm{a}+)$ tidak terdapat perbedaan.
Adanya perbedaan pada tingkat kecerahan dan tingkat kekuningan dapat disebabkan oleh penggunaan bahan baku dari masingmasing food bar.

Food bar formula 2 menggunakan grits kacang kedelai hitam beserta kulit dalam jumlah yang banyak dan bercampur dengan warna karamel hasil pemasakan binder sehingga membuat produk menjadi lebih gelap. Sedangkan food bar F menggunakan rice crispy dan oat yang memiliki karakteristik warna lebih cerah, selain itu tidak ada penambahan kulit kacang, serta proporsi binder yang digunakan juga lebih sedikit sehingga membuat produk menjadi lebih cerah.

Tabel 14 Hasil Analisis Warna Food Bar

\begin{tabular}{lccc}
\hline \multirow{2}{*}{ Food Bar } & \multicolumn{3}{c}{ Rerata Parameter } \\
\cline { 2 - 4 } & $(\mathrm{L})^{*}$ & $(\mathrm{a}+)^{*}$ & $(\mathrm{~b}+)^{*}$ \\
\hline Food Bar $(\mathrm{F} 2)$ & $44.3 \mathrm{c}$ & $4.3 \mathrm{a}$ & $12.3 \mathrm{c}$ \\
Food Bar CB & $51.9 \mathrm{~b}$ & $4.5 \mathrm{a}$ & $15.8 \mathrm{~b}$ \\
Food Bar F & $64.5 \mathrm{a}$ & $4.9 \mathrm{a}$ & $23.6 \mathrm{a}$ \\
\hline
\end{tabular}

Keterangan : $(*)$ Rerata yang didampingi dengan notasi huruf yang berbeda menunjukkan perbedaan yang sangat nyata $(\alpha=0,01)$

\section{Daya Patah}

Nilai daya patah $\left(\mathrm{N} / \mathrm{m}^{2}\right)$ ketiga food bar tidak berbeda nyata pada tingkat kepercayaan $99 \%$. Ketiga food bar memiliki nilai daya patah negatif, hal ini disebabkan oleh alat pengukur tekstur yang langsung menyentuh dasar produk dan terpental kembali karena produk sangat rapuh. Semakin rendah nilai $\mathrm{N} / \mathrm{m}^{2}$ maka semakin kecil gaya yang diberikan. Daya patah diasumsikan sebagai 
besar gaya yang dikeluarkan saat mengunyah. Daya patah produk bergantung pada karakteristik tekstur produk. Food bar yang bertekstur lebih lembut akan menghasilkan titik puncak yang lebih rendah dibandingkan yang bertekstur keras. Selain itu, daya patah juga dipengaruhi oleh persentase kadar air dan binder yang digunakan (Jauhariyah dan Tabel 15 Hasil Analisis Daya Patah Food Bar

\begin{tabular}{lc}
\multicolumn{1}{c}{ Food Bar } & Rerata Daya Patah $\left(\mathrm{N} / \mathrm{m}^{2}\right)$ \\
\hline Food Bar (F2) & -32.6 \\
Food Bar CB & -37.4 \\
Food Bar F & -31.2 \\
\hline
\end{tabular}

Keterangan : Nilai (-) menunjukkan tekstur produk sangat rapuh sehingga mudah patah

\section{KESIMPULAN}

Formulasi food bar grits kacang komak dan kacang kedelai hitam menggunakan linear programming menghasilkan 3 formula yang memiliki karakteristik kimia yang berbeda. Ketiga food bar dapat diterima dengan baik oleh kosumen berdasarkan tingkat kesukaan. Respon kenyang dan kepuasaan yang dihasilkan juga tidak berbeda nyata, namun jika dilihat berdasarkan keinginan makan dan penambahan kenyang hasilnya berbeda nyata.

Pemilihan formula terbaik berdasarkan parameter kimia, tingkat kenyang dan tingkat kesukaan dengan metode multiple attribute dan indeks efektivitas mengahasilkan formula 2. Formula 2 memiliki karakteristik kimia yaitu kadar lemak sebesar $19.00 \%$; kadar protein sebesar $13.07 \%$; kadar karbohidrat by different sebesar $58.08 \%$; kadar air sebesar $7.18 \%$; kadar abu sebesar $2.67 \%$; kadar serat kasar sebesar $3.14 \%$; dan total energi sebesar $455.6 \mathrm{kkal} / 100 \mathrm{~g}$. Karakteristik fisik untuk tingkat kecerahan (L) sebesar 44.3; tingkat kemerahan (a+) sebesar 4.3; tingkat kekuningan $(\mathrm{b}+)$ sebesar 12.3; dan untuk nilai daya patah sebesar $32.6 \mathrm{~N} / \mathrm{m} 2$. Food bar formula 2 dapat memenuhi kebutuhan energi manusia per hari, yaitu $2150 \mathrm{kkal}$ dengan mengonsumsi 910 kemasan yang tiap barnya mengandung $228 \mathrm{kkal} / 50 \mathrm{~g}$. Karakteristik tingkat kenyang formula 2 memiliki kenyang akhir 6.65, tingkat lapar panelis 7.29, keinginan makan panelis 5.18, kepuasan 6.87, indeks
Ayustaningwarno, 2013). Pada ketiga formula food bar, proporsi binder yang digunakan tidak jauh berbeda. Hasil analisis daya patah food bar dengan bahan baku tepung, seperti pada tepung komposit (pedada, talas dan kedelai) juga tidak memberikan perbedaan yang nyata (Jariyah et al., 2017).

(penambahan) kenyang 3.95. Karakteristik organoleptik pada formula 2 seperti nilai rata-rata 3.575 (suka) untuk warna; 3.750 (suka) untuk aroma; 3.700 (suka) untuk rasa; dan 3.425 (biasa/netral) untuk tekstur.

Saran dari penelitian ini yaitu hasil dari efek kenyang food bar dalam satu waktu (satiation) dapat diperkuat dengan efek kenyang berbanding waktu (satiety). Pembuktian akan efek kenyang juga dapat dibuktikan secara klinis dengan pengujian hormon kenyang dalam tubuh seperti PYY, GLP-1, dan ghrelin. Selain itu pengujian mengenai umur simpan produk fan pengujian senyawa anti-gizi, mengingat bahwa bahan baku produk adalah kacang-kacangan.

\section{DAFTAR PUSTAKA}

Aminah, S., Amalia, L., dan Hardianti, S. (2019). Karakteristik Kimia dan Organoleptik Snack Bar Biji Hanjeli (Coix lacryma jobi-L) dan Kacang Bogor (Vigna subterranea (L.) Verdcourt). Jurnal Agroindustri Halal 5: 212-219

Anindito, RBK., Siswanti, Nurhartadi, E., dan Hapsari, R. (2016). Formulasi Pangan Darurat Berbentuk Food Bars Berbasis Tepung Millet Putih (Panicum milliaceum L.) dan Tepung Kacang Merah (Phaseolus vulgaris L.). Agritech 36: 23-29

Association of Official Analytical Chemist. (1995). Official Methods ofAnalysis. $16^{\text {th }}$ 
Edition. Association of Official Analytical Chemist Inc. Mayland, USA.

Association of Official Analytical Chemist. (2005). Official Methods ofAnalysis. $18^{\text {th }}$ Edition. Association of Official Analytical Chemist Inc. Mayland, USA.

Badan Litbang Pertanian. (2012). Kedelai Hitam: Potensi Bahan Baku Industri. http://www.litbang.pertanian.go.id/berita /one/1175/ . [4 Januari 2018]

Badan Penelitian dan Pengembangan Pertanian. (2008). Potensi Bahan Baku Industri.

http://www.litbang.pertanian.go.id/berita /one/1175/. [12 Agustus 2017]

Blundell, J., Graaf, C. D., Hulshof, T., Jebb, S., Livingstone, B., Lluch, A., Mela., D., dan Salah, S. (2010). Appetite Control: Methodological Aspects of The Evaluation of Foods. Journal of Europe PMC Funders Group Volume 11: 251270.

Chambers, L., McCrickerd, K. dan Yeomans M.R. (2015). Optimising Food for Satiety. Trends in Food Science and Technology Volume 41: 149-160.

De Garmo, E. P., Sullivan, W. G., dan Canada, J. R. (1984). Engineering Economy. MacMillan Publishing Company. New York.

Fajri, R., Basito, dan Muhammad, DRA. (2013). Karakteristik Fisikokimia dan Organoleptik Food Bars Labu Kuning (Cucurbita maxima) dengan Penambahan Tepung Kedelai dan Tepung Kacang Hijau sebagai Alternatif Produk Pangan Darurat. Jurnal Teknologi Hasil Pertanian VI: 103-110

Febrial, E. (2009). Pengembangan Produk Pangan Fungsional Brownies Kukus Dari Tepung Kecambah dan Tepung Tempe Kacang Komak (Lablab purpureus (L.) sweet). Skripsi. Institut Pertanian Bogor. Bogor.

Fetriyuna. (2015). The Potential of Darmo Black Soybean Varieties as an Alternative of A Promising Food For Future. International Journal in
Advanced Science Engineering Information Technology 5: 44-46.

Gerstein, D. E., Lopez, G. W., Evans, A. E., Kelskey, K., dan Fewnowski, A. D. (2004). Clarifying Concepts about Macronutrients Effect on Satiation and Satiety. Journal of The American Dietetic Association. Volume 104: 1151 1153.

Heryani, H. (2016). Keutamaan Gula Aren dan Strategi Pengembangan Produk. Lambung Mangkurat University Press. Banjarmasin.

Hossein, S. Ahmed, R., Bhowmick, S., Almamun, A., dan Hashimoto, M. (2016). Proximate Composition and Fatty Acid Analysis of Lablab purpureus (L.) Legume Seed: Implicates to Both Protein and Essential Fatty Acid Supplementation. US National Library of Medicine Volume 5: 1899-1905.

Ibnas, R. (2014). Optimalisali Kasus Pemrograman Linear Dengan Metode Grafik dan Simpleks. Jurnal MSA 2: 18.

Jakobsen, L. M. A. (2015). Relation Between Food Structure and Induced Satiety, Macronutrient Uptake and Health. Denmark Department of Food Science.

Jariyah, B.S Karti, E., dan Pertiwi, YA. (2017). Evaluasi Sifat Fisikokimia Food bar dari Tepung Komposit (Pedada, Talas, dan Kedelai) Sebagai Alternatif Pangan Darurat. J. Rekapangan 11: 7075

Jauhariyah, D., dan Ayustaningwarno, F. (2013). Snack Bar Rendah Fosfor dan Protein Berbasis Produk Olahan Beras. Journal of Nutrition College 2: 250-261

Karalus, M. B. (2011). The Creation and Testing of a Scale to Measure the Subjective Experiences of Hunger and Satiety. Dissertation. University of Minnesota. United State of America.

Kusumastuty, I., Ningsih, L. F., dan Julia, A. R. (2015). Formulasi Food Bar Tepung Bekatul dan Tepung Jagung sebagai 
Pangan Darurat. Indonesian Journal of Human Nutrition 2: 68-75.

Ladamay, NA., dan Yuwono, SS. (2014). Pemanfaatan Bahan Lokal dalam Pembuatan Foodbars (Kajian Rasio Tapioka : Tepung Kacang Hijau dan Proporsi CMC). Jurnal Pangan dan Agroindustri 2: 67-78

Mayasari, S. (2010). Kajian Karakteristik Kimia dan Sensoris Sosis Tempe Kedelai Hitam (Glycine soja) dan Kacang (Phaseolus vulgaris) dengan Bahan Biji Berkulit dan Tanpa Kulit. Skripsi. Universitas Sebelas Maret. Surakarta

Mosisa, M.T. dan Tura, D.C. (2017). Effect of Processing on Proximate and Mineral Composition of Hepho, a Black Climbing Bean (Lablab purpureus L.) Flour. Journal of Food and Nutrition Sciences Volume 5: 16-22.

Pallavi BV., Chetana, R., Ravi, R., dan Reddy, SY. (2015). Moisture Sorption Curves of Fruit and Nut Cereal Bar Prepared with Sugar and Sugar Substitutes. Journal Food Science Technology 52: 1663-1669

Patel, K.D. dan Pandya, A.V. (2014). Assesment And Biochemical Analysis Of Black Soybean (With And Without Seed Coat). World Journal of Pharmaceutical Research Volume 3: 4272-4278.

Putri, N. E., Zakaria, F. R., Prangdimurti, dan E., Triandita, N. (2016). Pengaruh Intervensi Tahu Kedelai Hitam Kaya Serat Terhadap Glukosa Darah dan Inflamasi Responden Diabetes Tipe 2. Jurnal Teknologi dan Industri Pangan Volume 27: 131-139.

Rahman, T., Luthfiyanti, R. dan Ekafitri, R. (2011). Optimasi proses pembuatan food bar berbasis pisang. Prosiding SNaPP Sains, Teknologi, dan Kesehatan, Universitas Islam Bandung, Bandung, hal. 295-302.

Sinambela, S. D., Ariswoyo, S., dan Sitepu, H. R. (2014). Menentukan Koefisien Determinasi Antara Estimasi M dengan
Type Welsch dengan Least Trimmed Square dalam Data yang Mempunyai Pencilan. Saintia Mamtematika Volume 2 (3): 225-235.

Sudjarwo, E., Imam, M.F., dan Sjofjan, O. (2014). Efek Penggunaan Tepung Kacang Komak Mentah Sebagai Pengganti Bungkil Kedelai dalam Pakan Terhadap Kualitas Karkas Ayam Pedaging. Jurnal Fakultas Peternakan Universitas Brawijaya.

Syamsir, E. dan Sitanggang, PDL. (2011). Pengembangan Dodol sebagai Produk Pangan Darurat. Jurnal Ilmu dan Teknologi Pangan 9: 65-76

Ying, WS., Dian, NLHM., Wasoh, H., dan Ming, LO. (2018). Formulation of A Low Glycemic Binder Fortified with Palm Vitamin E (tocotrienol-rich fraction) for Functional Granola Bars. Journal of Oil Palm Research 30: 591601

Yusnandar, M. E. (2004). Aplikasi Analisis Regresi Non Linear Model Kuadratik Terhadap Produksi Susu Kambing Peranakan Etawah (Pe) Selama 90 Hari Pertama Laktasi. Informatika Pertanian Volume 13: 735-743.

Yuwono, S. S. dan Susanto, T. (1998). Pengujian Fisik Pangan. Fakultas Teknologi Pertaninan. Jurusan Teknologi Hasil Pertanian. Universitas Brawijaya. Malang.

Zar, J. H. (1972). Significance Testing of the Spearman rank correlation. Journal of the American Statistical Association. Volume 67: 578 - 580 .

Zeleny, M. 1982. Multiple Criteria Decision Making. Mc Graw Hill. New York

Zoumas, B. L., Armstrong, L. E., Backstrand, J.R., Chenoweth, W. L., Chinachoti, P., Klein, B. P., Lane, H. W., Marsh, K. S., Tolvanen, M. 2002. High-Energy, Nutrient-Dense Emergency Relief Food Product. National Academy Press. Washington DC. 